\title{
The effect of environmental sustainability on credit risk
}

\author{
André Höck $^{1,2} \cdot$ Christian Klein $^{1}\left[\right.$ (D) Alexander Landau $^{1,3}\left[\right.$ Bernhard Zwergel $^{1}$
}

Revised: 27 January 2020 / Published online: 7 March 2020

(c) The Author(s) 2020

\begin{abstract}
The European Commission has proposed establishing a framework that redirects capital to sustainable investments in order to foster sustainable economic growth. A key proposal from this framework is the mandatory consideration of environmental criteria for investment decisions. However, in particular for bond investors, there is not much academic guidance on how to integrate sustainability criteria in the investment process. Hence, this study investigates the impact of environmental sustainability on the pricing of credit risk for European corporations. Furthermore, whether or not the credit worthiness of a corporation has a moderating effect on the relationship between the environmental sustainability and the credit risk premium is analyzed. The findings prove that more sustainable companies have lower credit risk premiums if they also have a high credit worthiness.
\end{abstract}

Keywords Sustainability $\cdot$ Environment $\cdot$ Default risk measurement $\cdot$ CDS spreads

JEL Classification $\mathrm{G} 12 \cdot \mathrm{G} 32 \cdot \mathrm{M} 14 \cdot \mathrm{Q} 51$

\section{Introduction}

The European Union (EU) wants to support the transition to a more sustainable economy in accordance with international agreements, e.g., the Paris Climate Agreement, the UN 2030 Agenda and the Sustainable Development Goals. Therefore, the EU is in the process of establishing a framework, which redirects capital to sustainable investments. The first key step is the creation of a unified classification system ("taxonomy"), new sustainable benchmarks and sustainability-related disclosure obligations for assetmanagers. Furthermore, the EU plans to make it mandatory for asset managers to disclose whether and how they implement sustainability criteria in their investment processes. Even though the EU has a very comprehensive definition of sustainable investing, the main focus is on environmental issues, which includes minimizing green-house gas

André Höck

andrehoeck@googlemail.com

1 Department of Sustainable Finance, University of Kassel, Kassel, Germany

2 EB - Sustainable Investment Management GmbH, Kassel, Germany

3 Prof. Dr. Ludewig + Sozien, Kassel, Germany emissions, pollution and toxic waste as well as increasing the efficient use of natural resources (European Union 2019). So, investment professionals are faced with the challenge to find the best way to consider ecological criteria in their investment decisions.

The surge in academic studies covering the relationship between a company's sustainable and financial performance should provide enough insights to find a good solution for this challenge. Unfortunately, over 85 percent of the studies investigating this relationship are equitylinked (Friede et al. 2015), although bonds have a market share of almost 40 percent of sustainable investments in Europe (Eurosif 2018). Furthermore, the studies covering the impact of sustainability on bonds partly contradict each other. Most studies suggest that sustainability has a positive impact on credit risk (Friede et al. 2015). For example, the study from Oikonomou et al. (2014) shows that good corporate social performance leads to lower bond yields and better credit ratings. These findings are confirmed by other studies, which focus on the impact of environmental sustainability on credit risk (e.g. Bauer and Hann 2010; Graham and Maher 2006; Schneider 2011) or environmental and social sustainability on credit risk (Dorfleitner et al. 2019). However, some studies indicate a neutral or negative impact from sustainability on credit 
risk. For instance, the findings from Menz (2010) indicate that socially responsible companies have higher risk premiums than non-socially responsible firms.

In order to give investment professionals more clarity on how to incorporate environmental sustainability criteria into their fixed income investment process as well as to contribute to the current academic discussion, we investigate if the environmental sustainability of a company effects its default risk premium. We further investigate whether a firm's creditworthiness has a moderating effect on this relationship which could explain some of the different findings in the academic literature.

This study expands the existing body of research in three aspects. It is the first study in this field of research analyzing European corporations. This is of special interest due to the changing European regulatory framework which will force European investment firms to mandatorily disclose how they incorporate sustainability criteria in their investment process. Additionally, it is the first study to use credit default swap (CDS) spreads to measure credit risk in addressing the link between environmental sustainability and credit risk. The main advantage of using CDS spreads is that there is no need to correct for different maturities, coupon effects and other features, like optionality (Benkert 2004; Ericsson et al. 2009). Furthermore, this paper is the first that investigates the moderating effect of a company's credit quality on the relationship between their environmental sustainability score and credit risk while covering firms from all industry sectors, except financials.

To provide a comprehensive analysis, a sample with yearly data from 149 companies for the period from 2006 to 2017 is considered. The findings of the whole sample show that companies with higher environmental sustainability have lower credit spreads. However, the results of the subsamples are more heterogenous and highlight that only companies with a high creditworthiness profit from being environmentally sustainable. Market participants only reward companies with a high creditworthiness for being more sustainable, whereas companies with a lower creditworthiness have almost no advantage from their sustainability efforts. This highlights the importance of a sophisticated assessment, when implementing sustainability criteria in the investment process. Investment professionals should always consider the moderating role of a firm's creditworthiness in order to correctly assess the effect of sustainability on credit risk.

The remainder of this paper has the following structure: The next section presents the hypotheses development and gives a short review of the related literature. Chapter 3 explains the methodology and the data sample for the empirical analysis. This section is followed by the description of the main findings. Finally, this paper concludes with a short summary of the empirical results and an outlook on further research needs.

\section{Hypothesis development and related literature}

\section{Hypothesis development}

The default risk of a company could be negatively affected by a lack of environmental sustainability via four interconnected transmission channels. First, companies with a higher environmental sustainability have less regulatory risks because they have a lower probability of being fined for environmental misconduct and they are better prepared to adopt any regulatory changes regarding environmental issues. For example, the US Environmental Protection Agency (EPA) enforced private parties to spend over USD 450 million to cleanup Superfund sites in fiscal year 2018 (EPA 2019). Similar to the US Superfund, the EU put the Environmental Liability Directive (ELD) into force to prevent and remedy environmental damage based on the "polluter-pays" principle. This directive, which is enforced by the particular member states, is one European regulation that makes companies liable for the environmental damage they have caused (European Union 2006). Additionally, stricter regulations can be expected based on the Sustainable Development Strategy (SDS) of the European Union (European Union 2019). The implementation of these new regulations could pose a major challenge to environmental sinners and increase their compliance costs. In summary, the companies with lower environmental sustainability have a higher regulatory risk due to potentially higher fines as well as a slower and more costly adaption of upcoming regulatory changes which are expected to increase their default risk.

Second, companies with a lower environmental sustainability face higher stakeholder and reputational risks. The perception of environmental issues has changed leading to an increased public awareness and media coverage (Leiserowitz et al. 2018). Hence, many customers have become more sensitive to ecological issues and punish environmental misconduct by avoiding products from environmentally unfriendly companies, which can lead to a severe reduction in sales and harm profits. Additionally, other companies do not want to be associated with environmental sinners and thus are likely to cut off business dealings with polluters, which could have a negative impact on the whole supply chain. Bauer and Hann (2010) demonstrate that a deterioration of stakeholder relationships directly affects the cash flow, which influences both the firm value and the default risk.

Third, companies, which are involved in environmental issues, have a higher financial risk, because many investors 
start to integrate sustainability criteria in the investment process and thus either refuse to invest in those companies or demand a higher risk compensation. The EU plans to reinforce this development by introducing the EU taxonomy, ${ }^{1}$ sustainability-related disclosure for investment products and alternative sustainable benchmarks (European Union 2019). This is likely to redirect capital to more sustainable firms and thus lead to a further increase in refinancing costs for less sustainable companies. Additionally, banks and credit rating agencies start to incorporate sustainability criteria in their credit risk assessment process (Fitch Ratings 2019; Goss and Roberts 2011; Weber et al. 2008, 2010). Hence, less sustainable companies are likely to face higher refinancing costs for both loans and bonds if they receive lower credit ratings from banks and rating agencies, respectively. This will not only increase funding costs but also constrain access to sufficient funding sources in times of financial distress.

Fourth, companies, which are less sustainable, in particular in regard to environmental factors, have higher event risks. The Exxon Valdez (1985), BP (2010), Tepco (2011) and Vale (2019) catastrophes are a few examples that highlight the effect of environmental disasters on the creditworthiness of a company. For instance, the most recent disaster was the burst of Vale's dam in Brazil which led to the death of at least 248 people. Besides destroying the surrounding area, the whole ecosystem is now contaminated by metals which were released after the dam burst. As a result, Vale's stock price fell 24 percent after the catastrophe and their credit rating was reduced by Fitch to BBB. Furthermore, it significantly deteriorated their relationship with many stakeholders and will probably lead to stricter regulations. Vale could have prevented a decline in their creditworthiness, the deterioration of its stakeholder relationships and stricter regulations by better managing their environmental risks. The event risks that emerge from questionable business practices can lead to immense liabilities, which often question the continuation of the business and thus increase the default risk.

In summary, the higher regulatory, reputational, financial and event risk of companies with a lower environmental sustainability score is expected to negatively affect the creditworthiness of the respective company. Hence, our first hypothesis is as follows:

Hypothesis 1 Companies with higher environmental sustainability have lower credit risk premiums.

\footnotetext{
1 The EU taxonomy is a classification system for sustainable activities which aims to provide guidance for policy makers, industry and investors on how to best support and invest in economic activities that contribute to achieving a climate neutral economy.
}

The previously outlined risk-mitigation view, which states that higher sustainability leads to lower default risk, is widely held by researchers and investment professionals (e.g. Bauer and Hann 2010; Dorfleitner et al. 2019; Schneider 2011). However, some argue that investments in sustainability are a waste of scarce resources, which could be better spent by investing in the expansion of the firm or paying dividends. In accordance with this overinvestment view, the credit risk premia for more sustainable companies should be higher (e.g. Menz 2010). We hypothesize that companies with a high creditworthiness have more financial scope and are thus able to afford being "green." For them, the risk reduction effect from being sustainable overcompensates the additional costs. Furthermore, companies with a low creditworthiness have less financial scope, which makes it more difficult for them to direct their few resources towards sustainable development. Moderating effects could provide a link between the risk-mitigation view and the overinvestment view, as shown by Stellner et al. (2015) for the moderating effect of country sustainability on the relationship between credit risk and sustainability on company level. Based on these considerations, our second hypothesis is as follows:

Hypothesis 2 Only companies with a high creditworthiness profit from a high environmental sustainability.

\section{Related literature}

The first study regarding the effect of environmental sustainability on credit risk was conducted by Graham et al. (2001), who show that off-balance-sheet environmental obligations have a negative impact on bond ratings. Graham and Maher (2006) confirm these results and extend the previous work by investigating the impact of environmental liability information on bond yields. Their findings indicate that environmental obligations are accounted for in bond yields. However, the environmental liability information has no additional explanatory power if bond ratings are also considered in the model. The study from Schneider (2011) focusses on firms in the pulp and paper as well as chemical industry and highlights that poor environmental performance has a negative impact on bond pricing. Additionally, Bauer and Hann (2010) confirm the positive impact of good environmental management on bond ratings and yield spreads. However, their results indicate that there is no general industry or sector level effect moderating the effect of sustainability on credit risk due to the high heterogeneity of firms within these sectors. The most recent study in this field of research was conducted by Dorfleitner et al. (2019) which concludes that considering social and environmental criteria improves the prediction of credit ratings and that firms with a higher social or environmental sustainability receive better credit ratings. Additionally, we review the literature on 
green bonds, which are attracting growing investor interest. Hachenberg and Schiereck (2018) show that green bonds have a lower credit risk premium, which could be economically important, even though their results are often not statistically significant. In summary, the current literature regarding the impact of environmental sustainability on credit risk supports our first hypothesis.

In contrast, the moderating effect of creditworthiness on the impact of sustainability on credit risk is hardly analyzed by academics. Moreover, the few existing studies contradict each other. For instance, the findings of Schneider (2011) highlight that the effect of environmental sustainability on credit risk is more positive for U.S. companies from the pulp and paper as well as chemical industry if they have lower credit ratings. Goss and Roberts (2011) analyze loans from U.S. banks and investigate the impact a firm's investment in corporate social responsibility (CSR) has on its loan spreads. Their results contradict the findings from Schneider (2011), when they conclude that low-quality borrowers face higher refinancing costs if they invest in discretionary CSR.

To the best of our knowledge, this is the first study that analyzes the impact of environmental sustainability on credit risk for European companies using CDS spreads and investigates the moderating effect of creditworthiness while incorporating all industry sectors, except the financial sector, with an extensive sample ranging from 2006 to 2017.

\section{Data and methodology}

The starting point for the sample is the MSCI Europe Index, which includes more than 400 European firms. For this study financial firms are excluded from the sample for two reasons. First, companies from the financial sector have no essential impact on the environment and thus exhibit low direct environmental risks. They mainly face indirect environmental risks due to their loan portfolios, which have to be assessed differently. ${ }^{2}$ Second, credit risk models differ for financial and nonfinancial firms. For that reason, most studies regarding credit risk focus on companies from industrial sectors (e.g. Bai and Wu 2016; Ericsson et al. 2009). Additionally, all firms without a quoted CDS spread and sustainability data were excluded from the sample. So, the final sample comprises 149 European companies in the period from 2006 to 2017 based on yearly data.

In this study, CDS spreads are used instead of bond spreads to measure the default risk premium. There are three main advantages of using CDS spreads. First, CDS prices reflect changes in the firm-specific fundamental data faster

\footnotetext{
2 The impact of environmental sustainability on the credit risk of loans has been investigated by, for example, Weber et al. (2010).
}

and more accurately than bond prices, which tend to follow the CDS market (Blanco et al. 2005). Second, CDS is a pure measurement of credit risk. Hence, the CDS premium does not have to be separated into a term structure, credit risk and liquidity risk premium. Third, when CDS is used instead of bonds, it is not necessary to account for different and varying maturities due to their fixed tenor (Bai and $\mathrm{Wu}$ 2016; Ericsson et al. 2009). In accordance with Bai and Wu (2016), we use the natural logarithm of the CDS premium to accounted for variable skewness and to receive a better distributional behavior.

Based on prior studies, both fundamental and stock market data are used with the sustainability factor to explain the default risk premium of companies. In more detail, the fundamental data used in this study are leverage, profitability and market capitalization. Leverage, an indicator for the indebtedness of a company, is derived by dividing the total debt of a firm by its total assets. In accordance with the structural framework developed by Merton (1974), the distance-to-default shrinks if the leverage rises which ultimately leads to an increased default probability. In this framework, the default of a company is triggered if it has more debt than assets, which would be equal to a leverage ratio greater than 1 . Hence, companies with higher leverage have to pay higher risk premiums due to a higher default risk (Bai and Wu 2016; Collin-Dufresne et al. 2001). Profitability is measured by earnings before interest and taxes (EBIT) divided by the total assets. This figure should have a negative effect on the default risk because companies with higher earnings are more likely to repay their debt and thus less likely to default (Bai and Wu 2016; Benkert 2004). The last fundamental firm-specific variable is market capitalization, ${ }^{3}$ which is derived by multiplying a company's outstanding shares with its share price. Larger firms should have more financial flexibility than smaller firms which is why market capitalization is expected to also have a negative relationship with the default risk (Bai and Wu 2016; Du and Suo 2007; Shumway 2001).

In addition, two variables derived from the stock market are taken into account to explain the CDS prices. The first variable is the return of a company's stock measured as the annualized return of the stock during the last 180 trading days. Duffie et al. (2007) suggest in their study that a higher stock return leads to a lower credit risk premium. The other variable is the annualized volatility of a firm's stock, which is based on the daily stock returns of the last 180 trading days. In light of the structural framework, a firm's bond can be regarded as a short put option on the stock of the company whose value increases if the volatility of

\footnotetext{
3 Similar to the CDS, the natural logarithm of the market capitalization is used in the regression to account for skewness.
} 
Table 1 Overview of variables

\begin{tabular}{lll}
\hline Variable & Description & Source \\
\hline CDS & Natural logarithm of the CDS spread for the euro debt of a company & Bloomberg \\
RET & Annualized stock return from the last 180 trading days & Bloomberg \\
VOL & Annualized volatility of the stock from the last 180 trading days & Bloomberg \\
LEV & The leverage of a firm measured by total debt (euro) divided by total assets (euro) & Bloomberg \\
PROF & Profitability of a firm measured by EBIT (euro) divided by total assets (euro) & Bloomberg \\
Market Cap. & Natural logarithm of the market capitalization (euro), derived from shares outstanding times & Bloomberg \\
ENV & their market price & MSCI ESG Research \\
\hline
\end{tabular}

the respective stock increases (Campbell and Taksler 2003; Collin-Dufresne et al. 2001; Merton 1974). Thus, a higher stock volatility should be accompanied by a higher credit risk premium.

The environmental rating from MSCI is used in this study. ${ }^{4}$ This score measures the environmental sustainability of a company with a score ranging from 0 to 10 , whereby a higher score indicates a higher level of sustainability. The assessment of a company's environmental sustainability covers several key ecological issues with regard to climate change, natural resources, pollution and waste and environmental opportunities. Moreover, this sustainability rating takes the management of sustainability related risks as well as the exposure of the firm to those risks into account and weights the respective scores based on a firms' risk exposure (MSCI ESG Research 2018). Hence, the environmental score from MSCI is a very comprehensive assessment of the sustainability risks and opportunities a company faces. In accordance with our first hypothesis, we expect higher environmental sustainability to lead to lower CDS premiums due to less regulatory, reputational, financial and event risk.

All variables used in the regression are summarized in Table 1, which contains their abbreviations, short descriptions and the data source.

The following model uses a random-effects estimator ${ }^{5}$ with both time and individual dummies to account for unobserved time-variant and time-invariant effects. Additionally, time-clustered White standard errors ${ }^{6}$ are reported to correct

\footnotetext{
4 The correlation between environmental scores from different sustainability rating agencies is low (Berg et al. 2019; Dorfleitner et al. 2015). Thus, the results derived in this paper could change if sustainability scores from other agencies were used.

5 According to Wooldridge (2010), the Hausman test is not applicable, if the regression includes time fixed effects. We used the Mundlak (1978) approach instead to choose between the fixed and random effects model.

6 The Breusch-Pagan test and the Breusch-Godfrey/Wooldridge test indicated heteroscedasticity and serial-correlation, respectively. Hence, time clustered White standard errors are used to account for both heteroscedasticity and serial-correlation.
}

for heteroscedasticity and serial-correlation. The model is summarized in the following equitation:

$$
\begin{aligned}
\mathrm{CDS}_{i, t}= & \alpha+\beta_{1} \mathrm{RET}_{i, t}+\beta_{2} \mathrm{VOL}_{i, t}+\beta_{3} \mathrm{LEV}_{i, t} \\
& +\beta_{4} \mathrm{PROF}_{i, t}+\beta_{5} \operatorname{Market} \mathrm{Cap}_{i, t}+\beta_{6} \mathrm{ENV}_{i, t}+\varepsilon_{i, t}
\end{aligned}
$$

Similar to the methodology from Akdoğu and Alp (2016), subsamples are created to test for possible moderating effects by the creditworthiness of a firm. In order to analyze the effect of a firm's solvency, the subsamples are created based on the worst credit rating of each company assigned by Moody's, S\&P or Fitch. All of the corporations with a rating above the median rating are part of the good credit quality sample and vice versa. Additionally, three subsamples are built with the same sampling routine based on leverage, profitability and market capitalization. This process is repeated yearly to account for changes in the creditworthiness of the companies over time.

\section{Results}

In this section, we provide a detailed overview of our results for each hypothesis. First, the impact of the control variables on the CDS spread is discussed for every sample. After that, the general impact of environmental sustainability and the moderating effect of creditworthiness is analyzed. The results for the whole sample as well as for the respective subsamples are summarized in Table 2.

With two exception, all the control variables based on the stock market have the expected impact on the CDS spread, though only the effect of the stock volatility is significant. These results are logical in view of the structural framework because a bond has limited upside and unlimited downside potential. Hence, bond investors focus more on the possible losses, for which the stock volatility is a better estimator. Moreover, volatility is especially important for firms with a high leverage. This is plausible with regard to Merton's structural framework, as well, because a high leverage is 
Table 2 Regression results of the whole sample and the subsamples

\begin{tabular}{|c|c|c|c|c|c|c|c|c|c|}
\hline & \multicolumn{9}{|c|}{ Dependent variable: CDS } \\
\hline & \multirow[t]{2}{*}{ Whole sample } & \multicolumn{2}{|l|}{ Rating } & \multicolumn{2}{|l|}{ Leverage } & \multicolumn{2}{|l|}{ Profitability } & \multicolumn{2}{|l|}{ Market cap. } \\
\hline & & Good & bad & Low & High & High & Low & High & Low \\
\hline Constant & $\begin{array}{l}6.373 * * * \\
(0.229)\end{array}$ & $\begin{array}{l}5.231 * * * \\
(0.399)\end{array}$ & $\begin{array}{l}5.595 * * * \\
(0.433)\end{array}$ & $\begin{array}{l}6.909 * * * \\
(0.338)\end{array}$ & $\begin{array}{l}5.212 * * * \\
(0.348)\end{array}$ & $\begin{array}{l}5.620 * * * \\
(0.314)\end{array}$ & $\begin{array}{l}6.280 * * * \\
(0.327)\end{array}$ & $\begin{array}{l}6.234 * * * \\
(0.453)\end{array}$ & $\begin{array}{l}7.018 * * * \\
(0.516)\end{array}$ \\
\hline RET & $\begin{array}{l}-0.019 \\
(0.046)\end{array}$ & $\begin{array}{l}-0.061 \\
(0.099)\end{array}$ & $\begin{array}{l}-0.071 \\
(0.056)\end{array}$ & $\begin{array}{l}-0.001 \\
(0.061)\end{array}$ & $\begin{array}{l}-0.030 \\
(0.073)\end{array}$ & $\begin{array}{l}0.039 \\
(0.080)\end{array}$ & $\begin{array}{l}-0.048 \\
(0.059)\end{array}$ & $\begin{array}{l}0.008 \\
(0.066)\end{array}$ & $\begin{array}{l}-0.055 \\
(0.063)\end{array}$ \\
\hline VOL & $\begin{array}{l}2.091 * * * \\
(0.176)\end{array}$ & $\begin{array}{l}2.049 * * * \\
(0.348)\end{array}$ & $\begin{array}{l}2.124 * * * \\
(0.258)\end{array}$ & $\begin{array}{l}1.646^{* * * *} \\
(0.252)\end{array}$ & $\begin{array}{l}2.609 * * * \\
(0.257)\end{array}$ & $\begin{array}{l}2.338 * * * \\
(0.286)\end{array}$ & $\begin{array}{l}2.244 * * * \\
(0.229)\end{array}$ & $\begin{array}{l}2.356 * * * \\
(0.268)\end{array}$ & $\begin{array}{l}2.119 * * * \\
(0.238)\end{array}$ \\
\hline LEV & $\begin{array}{l}0.758 * * * \\
(0.140)\end{array}$ & $\begin{array}{l}0.819 * * * \\
(0.294)\end{array}$ & $\begin{array}{l}1.059 * * * \\
(0.205)\end{array}$ & $\begin{array}{l}1.098 * * \\
(0.461)\end{array}$ & $\begin{array}{l}0.976 * * * \\
(0.267)\end{array}$ & $\begin{array}{l}0.753 * * * \\
(0.203)\end{array}$ & $\begin{array}{l}0.650 * * * \\
(0.193)\end{array}$ & $\begin{array}{l}1.065^{* * * *} \\
(0.222)\end{array}$ & $\begin{array}{l}0.624 * * * \\
(0.178)\end{array}$ \\
\hline PROF & $\begin{array}{l}-2.112^{* * *} \\
(0.310)\end{array}$ & $\begin{array}{l}-2.213^{* * *} \\
(0.642)\end{array}$ & $\begin{array}{l}-1.943 * * * \\
(0.459)\end{array}$ & $\begin{array}{l}-1.891 * * * \\
(0.509)\end{array}$ & $\begin{array}{l}-2.276^{* * *} \\
(0.394)\end{array}$ & $\begin{array}{l}-2.114 * * * \\
(0.467)\end{array}$ & $\begin{array}{l}-1.803 * * * \\
(0.717)\end{array}$ & $\begin{array}{l}-2.530 * * * \\
(0.546)\end{array}$ & $\begin{array}{l}-1.638^{* * *} \\
(0.373)\end{array}$ \\
\hline Market Cap. & $\begin{array}{l}-0.263 * * * \\
(0.019)\end{array}$ & $\begin{array}{l}-0.146^{* * *} \\
(0.033)\end{array}$ & $\begin{array}{l}-0.182^{* * *} \\
(0.041)\end{array}$ & $\begin{array}{l}-0.302 * * * \\
(0.027)\end{array}$ & $\begin{array}{l}-0.176^{* * *} \\
(0.029)\end{array}$ & $\begin{array}{l}-0.202^{* * *} \\
(0.026)\end{array}$ & $\begin{array}{l}-0.259 * * * \\
(0.028)\end{array}$ & $\begin{array}{l}-0.242^{* * *} \\
(0.038)\end{array}$ & $\begin{array}{l}-0.344 * * * \\
(0.053)\end{array}$ \\
\hline ENV & $\begin{array}{l}-0.018^{*} \\
(0.010)\end{array}$ & $\begin{array}{l}-0.043^{* * *} \\
(0.016)\end{array}$ & $\begin{array}{l}-0.007 \\
(0.015)\end{array}$ & $\begin{array}{l}-0.032 * * \\
(0.015)\end{array}$ & $\begin{array}{l}-0.001 \\
(0.013)\end{array}$ & $\begin{array}{l}-0.009 \\
(0.013)\end{array}$ & $\begin{array}{l}-0.011 \\
(0.014)\end{array}$ & $\begin{array}{l}-0.042^{* * *} \\
(0.013)\end{array}$ & $\begin{array}{l}-0.007 \\
(0.014)\end{array}$ \\
\hline$R^{2}$ & 0.499 & 0.420 & 0.470 & 0.495 & 0.508 & 0.455 & 0.494 & 0.542 & 0.471 \\
\hline Adj. $R^{2}$ & 0.496 & 0.410 & 0.460 & 0.489 & 0.502 & 0.448 & 0.488 & 0.537 & 0.464 \\
\hline Obs. & 1.003 & 365 & 350 & 526 & 475 & 476 & 525 & 500 & 499 \\
\hline$F$ stats & $\begin{array}{l}158.271 * * * \\
(d f=6 ; 996)\end{array}$ & $\begin{array}{l}37.718 * * * \\
(d f=6 ; 358)\end{array}$ & $\begin{array}{l}45.840 * * * \\
(d f=6 ; 343)\end{array}$ & $\begin{array}{l}81.269 * * * \\
(d f=6 ; 519)\end{array}$ & $\begin{array}{l}75.868 * * * \\
(d f=6 ; 468)\end{array}$ & $\begin{array}{l}59.926 * * * \\
(d f=6 ; 469)\end{array}$ & $\begin{array}{l}79.489 * * * \\
(d f=6 ; 518)\end{array}$ & $\begin{array}{l}84.450 * * * \\
(d f=6 ; 493)\end{array}$ & $\begin{array}{l}68.392 * * * \\
(d f=6 ; 492)\end{array}$ \\
\hline
\end{tabular}

This table presents the estimated coefficients and standard-errors (in parentheses) from the random effects model of the natural logarithm of the CDS spreads on the environmental-score as well as fundamental and market control variables for the whole sample and the different subsamples, which differ in terms of particular fun-damental characteristics (rating, leverage, profitability and market capitalization). To account for heteroscedasticity as well as serial auto-correlation time clustered White standard errors are reported. ***, **, * denote statistical significance at the $1 \%, 5 \%$ and $10 \%$ level, respectively

associated with a low distance-to-default which reinforces the effect of the stock volatility.

The fundamental variables have the expected effect on the CDS spread as well. Both profitability and market capitalization have a negative effect on the CDS premium. That means, companies that are more profitable and have a higher market capitalization have a lower credit risk. Furthermore, profitability seems to be particularly crucial for companies with a high creditworthiness. Thus, investors view profitability as the more important factor when distinguishing between firms with an already good solvency. The last control variable is leverage which also has the expected impact on the CDS premiums. In all samples, a higher leverage leads to an increase in the default risk premium.

The findings based on the whole sample show that the environmental factor has a negative impact on the CDS spread. Hence, firms with a higher environmental sustainability have, in general, lower CDS spreads.

This finding supports our first hypothesis, which stated, with regard to the risk-mitigation view, that more sustainable firms have a lower default probability and have to pay less for their debt due to lower regulatory, reputational, financial and event risks. For instance, companies that increase their environmental score by 1 point can decrease their CDS spread by 1.8 percent. Thus, a company that has a CDS spread of $122.9 \mathrm{bp}$, which is the average CDS premium of the whole sample, can decrease their CDS spread by $2.1 \mathrm{bp}$ by increasing their environmental score by 1 point.

After analyzing the general impact of environmental sustainability on CDS spreads, we elaborate on the potential moderating effect of a company's credit quality. Even though the effect of environmental sustainability remains negative, irrespective of the subsample, the magnitude of the effect varies notably between the different samples. For example, environmental sustainability has almost no effect on companies with a low credit rating. In contrast, environmental sustainability has a big influence on the credit risk premium of companies that have high credit ratings and good creditworthiness. Moreover, the effect is strong for companies with a low leverage and high market capitalization, whereas it does not pay of to be green for small and indebted companies, though they do not incur a penalty for 
being sustainable. Profitability is the only variable that does not affect the impact of sustainability on CDS premiums. The impact on firms with either a high or low profitability is almost the same and, in both cases, not statistically significant. A reason for this result could be that leverage and market capitalization are more important indicators for a firm's ability to fund its sustainable development. So, if a firm has a high leverage or a low market capitalization, the investors prefer paying debt off or retaining the earnings to investing in the environmental sustainability, irrespective of the profitability. In particular, the results for the subsamples based on the credit ratings confirm our second hypothesis and show that only companies with a high creditworthiness profit from a high environmental sustainability.

\section{Conclusion}

In this paper we analyzed, whether environmental sustainability has an effect on the credit risk of European nonfinancial companies to help investors making sound decisions, when incorporating sustainability into their investment process. This topic is expected to gain even more importance in view of the upcoming EU directives based on their sustainable development strategy, which will directly affect both asset owners and investment managers.

In general, the findings show that more sustainable companies have a lower credit risk due to lower reputational, financial, regulatory and event risks, which provides proof for our first hypothesis and the risk-mitigation view. Furthermore, our findings indicate that a company's creditworthiness moderates the impact of environmental sustainability on credit risk. It appears that only companies with high creditworthiness benefit from having a high environmental sustainability score, though companies with a low creditworthiness do not incur a penalty for being sustainable.

Therefore, investment professionals should integrate environmental criteria into the assessment of a company's default risk and consider the moderating effect of a firm's creditworthiness. This integration should improve existing credit models and lead to a slightly more precise valuation of credit risk.

Further research should expand this study by analyzing the impact of sustainability on the credit risk of companies which have a sub-investment grade credit rating or are from emerging market countries because investors tend to shift their assets into these asset classes in a search for yield and need precise valuation models, which incorporate sustainability data. Additionally, the impact of the new EU regulations on the pricing and allocation of loans could be further investigated to better understand whether the perception of environmental risks within the credit portfolios of banks and other financial firms is changing.
Acknowledgments Open Access funding provided by Projekt DEAL.

Open Access This article is licensed under a Creative Commons Attribution 4.0 International License, which permits use, sharing, adaptation, distribution and reproduction in any medium or format, as long as you give appropriate credit to the original author(s) and the source, provide a link to the Creative Commons licence, and indicate if changes were made. The images or other third party material in this article are included in the article's Creative Commons licence, unless indicated otherwise in a credit line to the material. If material is not included in the article's Creative Commons licence and your intended use is not permitted by statutory regulation or exceeds the permitted use, you will need to obtain permission directly from the copyright holder. To view a copy of this licence, visit http://creativecommons.org/licenses/by/4.0/.

\section{Appendix}

\begin{tabular}{|c|c|c|c|c|c|c|c|}
\hline \multicolumn{8}{|c|}{ Descriptive statistics of variables } \\
\hline & Min. & $25 \%$ & Median & Mean & $75 \%$ & Max. & Obs. \\
\hline CDS & 3.7 & 49.2 & 73.9 & 122.9 & 129.7 & 3551.3 & 1562 \\
\hline RET & -0.921 & -0.139 & 0.053 & 0.093 & 0.275 & 8.789 & 1756 \\
\hline VOL & 0.065 & 0.207 & 0.254 & 0.289 & 0.333 & 1.715 & 1760 \\
\hline LEV & 0.001 & 0.185 & 0.257 & 0.285 & 0.373 & 0.966 & 1816 \\
\hline PROF & -0.270 & 0.043 & 0.065 & 0.074 & 0.099 & 0.445 & 1816 \\
\hline $\begin{array}{c}\text { Market } \\
\text { Cap. }\end{array}$ & 525.1 & 8029.0 & $16,255.5$ & $29,035.2$ & $34,391.1$ & $232,241.3$ & 1749 \\
\hline ENV & 1.710 & 5.468 & 6.500 & 6.538 & 7.500 & 10.000 & 1156 \\
\hline
\end{tabular}

This table shows the key descriptive statistics of all variables used in the regression. The variables are presented without being normalized by logarithms and the unit of the market capitalization is million

\begin{tabular}{lrlllllr}
\hline \multicolumn{2}{l}{ Pearson correlation of variables } \\
\hline & CDS & RET & VOL & LEV & PROF & $\begin{array}{l}\text { Market } \\
\text { Cap. }\end{array}$ & ENV \\
\hline CDS & 1.000 & -0.245 & 0.670 & 0.130 & -0.276 & -0.443 & -0.016 \\
RET & -0.245 & 1.000 & -0.278 & -0.012 & 0.055 & 0.108 & -0.034 \\
VOL & 0.670 & -0.278 & 1.000 & -0.048 & -0.187 & -0.359 & -0.019 \\
LEV & 0.130 & -0.012 & -0.048 & 1.000 & 0.133 & -0.033 & 0.085 \\
PROF & -0.276 & 0.055 & -0.187 & 0.133 & 1.000 & 0.122 & -0.006 \\
Market & -0.443 & 0.108 & -0.359 & -0.033 & 0.122 & 1.000 & 0.000 \\
Cap. & & & & & & & \\
ENV & -0.016 & -0.034 & -0.019 & 0.085 & -0.006 & 0.000 & 1.000 \\
\hline
\end{tabular}

This table shows the Pearson correlation of all variables used in the regression

\section{References}

Akdoğu, E., and A. Alp. 2016. Credit Risk and Governance: Evidence from Credit Default Swap Spreads. Financial Research Letters 17: $211-217$. 
Bai, J., and L. Wu. 2016. Anchoring Credit Default Swap Spreads to Firm Fundamentals. Journal of Financial and Quantitative Analysis 51(5): 1521-1543.

Bauer, R., and D. Hann. 2010. Corporate Environmental Management and Credit Risk. Maastricht University, ECCE, working paper.

Benkert, C. 2004. Explaing Credit Default Swap Premia. Journal of Futures Markets 24(1): 71-92.

Berg, F., J. Koelbel, and R. Rigobon. 2019. Aggregate Confusion: The Divergence of ESG Ratings. MIT Sloan School of Management, working paper.

Blanco, R., S. Brennan, and I.W. Marsh. 2005. An Empirical Analysis of the Dynamic Relationship Between Investment-Grade Bonds and Credit Default Swaps. Journal of Finance 60(5): 2255-2281.

Campbell, J.Y., and G.B. Taksler. 2003. Equity Volatility and Corporate Bond Yields. Journal of Finance 58(6): 2321-2349.

Collin-Dufresne, P., R.S. Goldstein, and J.S. Martin. 2001. The Determinants of Credit Spread Changes. Journal of Finance 56(6): 2177-2207.

Dorfleitner, G., J. Grebler, and S. Utz. 2019. The Impact of Corporate Social and Environment Performance on Credit Rating Prediction: North America versus Europe. University of Regensburg, working paper.

Dorfleitner, G., G. Halbritter, and M. Nguyen. 2015. Measuring the Level and Risk of Corporate Responsibility: An Empirical Comparison of Different ESG Rating Approaches. Journal of Asset Management 16(7): 450-466.

Du, Y., and W. Suo. 2007. Assessing Credit Quality from the Equity Market: Can a Structural Approach Forecast Credit Ratings? Canadian Journal of Administrative Science 24(3): 212-228.

Duffie, D., L. Saita, and K. Wang. 2007. Multi-period Corporate Default Prediction with Stochastic Covariates. Journal of Financial Economics 83(3): 635-665.

Ericsson, J., K. Jacobs, and R. Oviedo. 2009. The Determinants of Credit Default Swap Spread. The Journal of Financial and Quantitative Analysis 44(1): 109-132.

European Union. 2006. Environmental Liability Directive: A Short Overview. http://ec.europa.eu/environment/legal/liability/pdf/ SummaryELD.pdf. Accessed 10 September 2019.

European Union. 2019. Financing Sustainable Growth. https://ec.europ a.eu/info/sites/info/files/business_economy_euro/accounting _and_taxes/documents/190618-sustainable-finance-factsheet_ en.pdf. Accessed 17 September 2019.

Eurosif. 2018. European SRI study 2018. http://www.eurosif.org/ wp-content/uploads/2018/11/European-SRI-2018-Study.pdf. Accessed 20 September 2019.

Fitch Ratings. 2019. Press Announcement: Fitch Ratings Launches ESG Relevance Scores to Show Impact of ESG on Credit. https:// www.fitchratings.com/site/pr/10058528. Accessed 17 June 2019.

Friede, G., T. Busch, and A. Bassen. 2015. ESG and Financial Performance: Aggregated Evidence from More than 2000 Empirical Studies. Journal of Sustainable Finance and Investment 5(4): 210-233.

Goss, A., and G.S. Roberts. 2011. The Impact of Corporate Social Responsibility on the Cost of Bank Loans. Journal of Banking \& Finance 35(7): 1794-1810.

Graham, A., and J.J. Maher. 2006. Environmental Liabilities, Bond Ratings, and Bond Yields. Environmental Accounting 3: 111-142.

Graham, A., J.J. Maher, and W.D. Northcut. 2001. Environmental Liability Information and Bond Ratings. Journal of Accounting, Auditing and Finance 16(2): 93-116.

Hachenberg, B., and D. Schiereck. 2018. Are Green Bonds Priced Differently from Conventional Bonds? Journal of Asset Management 19(6): 371-383

Leiserowitz, A., E. Maibach, S. Rosenthal, J. Kotcher, M. Ballew, and A. Gustafson. 2018. Climate Change in the American Mind:
December 2018. New Haven, CT: Yale Program on Climate Change Communication.

Menz, K.M. 2010. Corporate Social Responsibility: Is it Rewarded by the Corporate Bond Market? A Critical Note. Journal of Business Ethics 96(1): 117-134.

Merton, R.C. 1974. On the Pricing of Corporate Debt: The Risk Structure of Interest Rates. Journal of Finance 29(2): 449-470.

MSCI ESG Research. 2018. MSCI ESG Ratings Methodology - Executive Summary. https://www.msci.com/documents/10199/123a2 b2b-1395-4aa2-a121-ea14de6d708a. Accessed 18 September 2019.

Mundlak, Y. 1978. On the Pooling of Time Series and Cross Section Data. Econometria 46(1): 69-85.

Oikonomou, I., C. Brooks, and S. Pavelin. 2014. The Effects of Corporate Social Performance on the Cost of Corporate Debt and Credit Ratings. Financial Review 49(1): 49-75.

Schneider, T.E. 2011. Is Environmental Performance a Determinant of Bond Pricing? Evidence from the U.S. Pulp and Paper and Chemical Industries. Contemporary Accounting Research 28: $1537-1561$

Shumway, T. 2001. Forecasting Bankruptcy More Accurately: A Simple Hazard Model. Journal of Business 74(1): 101-124.

Stellner, C., C. Klein, and B. Zwergel. 2015. Corporate Social Responsibility and Eurozone Corporate Bonds: The Moderating Role of Country Sustainability. Journal of Banking \& Finance 59: 538-549.

Weber, O., M. Fenchel, and R.W. Scholz. 2008. Empirical Analysis of the Integration of Environmental Risks into the Credit Risk Management Process of European Banks. Business Strategy and the Environment 17: 149-159.

Weber, O., R.W. Scholz, and G. Michalik. 2010. Incorporating Sustainability Criteria into Credit Risk Management. Business Strategy and the Environment 19: 39-50.

Wooldridge, J.M. 2010. Econometric Analysis of Cross Section and Panel Data. Cambridge: The MIT Press.

Publisher's Note Springer Nature remains neutral with regard to jurisdictional claims in published maps and institutional affiliations.

André Höck is Head of Portfolio Management Fixed Income at EBSustainable Investment Management GmbH (EB-SIM). Prior to his current position, he was Senior Portfolio Manager at EB-SIM and responsible for the Corporate Bond Strategies focusing on Europe and the Emerging Markets. Before joining the Chair of Corporate Finance at the University of Kassel as a Ph.D. candidate, he graduated in Banking and Finance from the Steinbeis University, Germany. His research activities are focused on the effect of sustainability on credit risk.

Prof. Dr. Christian Klein is a professor of Corporate Finance and Sustainable Finance at the University of Kassel. One of his main research areas focuses on what motivates investors to choose a sustainable approach in investing. In this research area, he normally performs empirical studies. He has studied Economics and Management in Augsburg/Germany and Swansea/United Kingdom. After his studies, he worked for one year at Siemens AG, Munich. Following this experience, he accepted an employment at University of Augsburg as scientific co-worker and finally graduated on the subject "Irrational Behaviorism on Capital Markets" (summa cum laude). At Hohenheim, he wrote his thesis for habilitation entitled "New Anomalies of Capital Markets and Disappearing Anomalies." He was awarded the ErichGutenberg prize for young scientists in 2009. He received the Hohenheimer teaching award for his teaching accomplishments and was voted business teacher of the year at the University of Augsburg. 
Alexander Landau graduated in Business Studies from the University of Kassel, Germany, in 2016. In 2016, he joined the Chair of Corporate Finance at the University of Kassel, Germany, as a Ph.D. candidate. Since 2016, he has been an Auditor at Prof. Dr. Ludewig + Partner (auditing firm) in Kassel, Germany. His research activities are focused on the Value Relevance of Environmental, Social and Governance Reporting.

Bernhard Zwergel graduated in business administration from the University of Augsburg, Germany, in 2004. In 2009, he received his $\mathrm{Ph} . \mathrm{D}$. degree from the same university. Since 2013, he has been a postdoctoral research fellow at the Chair of Corporate Finance at the University of Kassel. His research activities are focused on the analysis of the behavior of (sustainable) private investors and the performance measurement and design of sustainable investment products (e.g. bonds, funds and indices). 